DOI.

https://doi.org/10.22219/fths.v3i1

Received: Desember 2019

Accepted: Januari 2020

Available online: Februari 2020

\title{
Daya Terima, Zat Gizi, dan Nilai Energi Roti Tawar Anti- Diabetes dengan Penambahan Sari Mengkudu (Morinda citrifolia L.)
}

\author{
Rista Anggriani1 ${ }^{*}$, Nurul Laelatunisa ${ }^{1}$, Nikmatul Rizky1$^{1}$, Rachmadhanti Arum $^{1}$ \\ ${ }^{1}$ Program Studi Teknologi Pangan, Fakultas Pertanian Peternakan, Universitas \\ MuhammadiyahMalang, Malang, Indonesia
}

*Corresponding author email: rista@umm.ac.id

\begin{abstract}
White bread is a popular food product in Indonesia which is dominated by carbohydrate content. To improve its functional, the noni juice which has phytochemical compounds of the alkaloid group was added. However, noni has a very strong aroma, which makes this noni rarely processed. This study aims to analyze the nutritional content, energy value and organoleptic test of white bread added with noni juice. This research used descriptive experimental design that the data is compared with SNI No 013840-1995 of white bread (Standar Nasional Indonesia = Indonesia Standar Requirement). Noni juice is added by four levels (0, 50, 150, 250ml). The results found that the more noni juice added would cause the addition of flour used, thereby increasing the calories per serving. In addition, the addition of noni juice causes an increase in brown color and aroma, but decreases the softness, and sweetness of white bread.
\end{abstract}

Keywords: calorie changes, noni juice, sensory enhancements, white bread formulations

\section{PENDAHULUAN}

Roti tawar merupakan pilihan roti yang digemari oleh masyarakat Indonesia. Hal ini dibuktikan dengan maraknya toko-toko "bakery" di berbagai daerah dengan harga yang beraneka macam. Nilai konsumsi roti di Indonesia naik $25 \%$ pada 2011 menjadi US $\$ 1,5$ per orang per tahun, dari konsumsi US $\$ 1,2$ per orang per tahun pada 2010 (Gandama, 2012).

Selama ini, roti tawar yang merupakan olahan berbasis terigu hanya dikenal sebagai sumber energi. Untuk itulah, banyak penelitian yang mencoba untuk memformulasikan roti tawar dengan bahan-bahan lain untuk menambah sisi fungsionalnya. Sugiharto dkk (2016) menambahkan minyak ikan sebagai sumber antioksidan pada roti tawar, sementara Lestari dkk (2016) mensubstitusi tepung kacang koro sebagai penambah protein pada roti tawar.

Laelatunisa dkk (2019) menambahkan penambahan sari mengkudu sampai $250 \mathrm{~mL}$ pada roti tawar yang menunjukkan adanya aktivitas penurunan darah sampai $37 \%$ pada mencit putih yang diinduksi dengan aloksan. Hal ini membuktikan bahwa mengkudu (Morinda citrifolia L) memiliki kandungan 
senyawa metabolit sekunder yang bermanfaat bagi kesehatan tubuh manusia. Senyawa bioaktif yang terdeteksi berpotensi sebagai senyawa antidiabetes pada roti tawar dengan penambahan sari mengkudu adalah golongan alkaloid.

Akan tetapi pada penelitian Laelatunisa dkk (2019) belum dilakukan analisa tentang berapa nilai kalori roti tawar tersebut. Menurut Baequny dkk (2015) menyatakan bahwa terdapat pengaruh pola makan tinggi kalori terhadap peningkatan kadar gula darah pada penderita Diabetes Mellitus Tipe 2. Nilai kalori sebagai takaran energi dalam makanan dapat dihitung berdasarkan Pedoman BPOM (2005).

Selain itu roti tawar dari hasil penelitian Laelatunisa dkk (2019), belum diujikan tentang daya terimanya melalui uji organoleptik. Hal ini penting karena mengkudu mempunyai aroma yang kuat ketika mulai matang yang kurang disukai oleh masyarakat. Untuk itu perlu dilakukan uji penerimaan roti tawar yang ditambahkan sari mengkudu melalui uji sensori. Uji sensori merupakan cara untuk mengetahui kualitas produk dalam hal cita rasa produk yang dapat memenuhi harapan konsumen. Uji hedonic diterapkan di penelitian ini sebagai salah satu cara uji sensori untuk mengetahui perbedaan kualitas dan tingkat kesukaan diantara beberapa produk sejenis dengan sistem skoring (Stone dan Joel, 2004). Oleh karena itu, peneliti menganalisa nilai gizi dan energi serta tingkat penerimaan konsumen melalui uji organoleptik, agar roti tawar dengan penambahan sari mengkudu ini selain mempunyai aktivitas antidiabetes, juga diketahui nilai kalorinya dan bisa diterima oleh konsumen secara cita rasa.

\section{METODE PENELITIAN}

\section{Bahan}

Buah mengkudu yang didapatkan dari pasar lokal Malang.

Alat

Pembuatan sari mengkudu

Buah mengkudu diolah menjadi sari mengkudu dengan mengikuti metode Laetanunisa dkk (2019).

\section{Formulasi Roti Tawar dengan penambahan dari mengkudu}

Pembuatan roti tawar dengan penambahan sari buah mengkudu mengikuti hasil penelitian terdahulu (Laetanunisa dkk, 2019). Akan tetapi pada penelitian ini, sari mengkudu yang ditambahkan $50 \mathrm{~mL}, 100 \mathrm{~mL}, 150 \mathrm{~mL}$, dan $250 \mathrm{~mL}$. Formulasi yang digunakan dapat dilihat pada Tabel 1. 
Tabel 1.Formula Pembuatan Roti Tawar Mengkudu

\begin{tabular}{l|r|r|r|r|r}
\hline Komposisi Bahan & $\begin{array}{r}\text { Formula } \\
1\end{array}$ & Formula 2 & Formula 3 & Formula 4 & Formula 5 \\
\hline Tepung Terigu (g) & 250,00 & 250,00 & 290,00 & 340,00 & 400,00 \\
Margarin (g) & 75,00 & 75,00 & 75,00 & 75,00 & 75,00 \\
Telur (g) & 25,00 & 25,00 & 25,00 & 25,00 & 25,00 \\
Gula (g) & 25,00 & 25,00 & 25,00 & 25,00 & 25,00 \\
Susu (g) & 6,00 & 6,00 & 6,00 & 6,00 & 6,00 \\
Ragi (g) & 3,75 & 3,75 & 3,75 & 3,75 & 3,75 \\
Garam (g) & 3,75 & 3,75 & 3,75 & 3,75 & 3,75 \\
Bread Impover (g) & 0,75 & 0,75 & 0,75 & 0,75 & 0,75 \\
TOTAL (g) & 389,25 & 389,25 & $\mathbf{4 2 9 , 2 5}$ & $\mathbf{4 7 9 , 2 5}$ & $\mathbf{5 3 9 , 2 5}$ \\
Air (ml) & 150,00 & - & - & - & - \\
Sari Mengkudu & - & 50,00 & 100,00 & 150,00 & 250,00 \\
(ml) & & & & & \\
\hline
\end{tabular}

\section{Analisa Proksimat}

Analisis kandungan gizi roti tawar meliputi kadar air metode oven (AOAC, 2005), kadar protein metode Mikro Kjeldhal (Legowo et al, 2005), kadar lemak metode ekstraksi soxhlet (Legowo et al, 2005), kadar karbohidrat metode by difference (AOAC, 2005), kadar abu (Sudarmadji, 1997). Analisa gula total metode Anthrone (AOAC, 2005) dilakukan pada sari mengkudu dan roti tawar.

\section{Perhitungan Energi}

Perhitungan nilai energi didasarkan pada Almatsier (2004) dan perhitungan Angka Kecukupan Gizi (AKG) pada diet 2000 kkal dengan pencantuman informasi nilai gizi mengikuti BPOM (2005).

\section{Uji Organoleptik}

Untuk mengetahui tingkat kesukaan terhadap roti mengkudu dilakukan uji hedonik yang meliputi rasa, warna, tekstur, dan aroma. Panelis yang digunakan merupakan panelis tidak terlatih sebanyak 25 orang.

\section{Rancangan Percobaan dan Analisa data}

Penelitian ini merupakan penelitian eksperimental dengan satu faktor yaitu volume sari mengkudu yang ditambahkan pada adonan roti tawar dengan 4 perlakuan. Data yang diperoleh dianalisa secara deskriptif dengan dibandingkan SNI No 01-3840-1995 tentang syarat mutu roti tawar. Data yang dihasilkan disajikan secara deskriptif meliputi data proksimat, perhitungan kalori dan uji organoleptik. 


\section{HASIL DAN PEMBAHASAN}

\section{Formulasi Roti Tawar dengan Penambahan Sari Mengkudu}

Jumlah tepung terigu dalam formulasi roti tawar untuk ketiga perlakuan (penambahan sari mengkudu 100,150,250 mL) tidak bisa dibuat sama beratnya (Tabel 1) dengan formula 1 (kontrol) dikarenakan semakin tinggi volume sari mengkudu yang ditambahkan maka adonan semakin encer, sehingga dilakukan penambahan tepung terigu untuk membuat adonan kalis. Oleh karena itu, analisa kimia dan organoleptik tidak dilakukan pada formula 5 dengan alasan selisih jumlah terigu yang ditambahkan sudah terlalu banyak dibandingkan dengan formula 1 (kontrol).

Hal ini diduga dikarenakan pengaruh $\mathrm{pH}$ dari sari mengkudu yang digunakan. Ketika air diganti dengan sari mengkudu yang bersifat asam (hasil pengecekan penelitian ini menunjukkan $\mathrm{pH}$ 5), maka mempengaruhi adonan. Menurut Sudarno (2015), air yang terbaik untuk pembuatan roti tawar adalah air dengan tingkat kesadahan rendah. Air sangat menentukan konsistensi dan karakteristik reologi adonan. Sari mengkudu sebagai pengganti air pada formula 2-4, diduga mempunyai kandungan mineral yang banyak, sehingga mempengaruhi konsistensi adonan.

\section{Nilai Gizi Roti Tawar dengan Penambahan Sari Mengkudu}

Pada Tabel 2 menunjukkan bahwa kadar air roti tawar yang paling tinggi adalah pada perlakuan formula 1 yang tanpa ditambahkan sari mengkudu, sedangkan kadar air pada roti tawar akan semakin menurun seiring peningkatan volume sari mengkudu yang digunakan. Hal ini diduga karena perbedaan kandungan air pada pelarut adonan yang digunakan. Dari hasil penelitian ini, sari mengkudu mempunyai kandungan lain selain air, yakni terdeteksi adanya total gula sebesar $3,46 \%$. Selain itu, pada saat proses filtrasi di pembuatan sari mengkudu, diduga masih terdapat padatan-padatan yang terlarut. Sehingga kandungan air pada sari mengkudu tidaklah sebanyak pada air. Akibatnya, kadar air yang terdeteksi pada roti tawar juga lebih rendah dibanding roti tawar yang menggunakan air pada saat menguleni adonan. Meskipun demikian, terdapat regulasi SNI No 01-3840-1995 tentang syarat mutu roti tawar yang menyebutkan syarat kadar air maksimal $40 \%$. Sehingga roti tawar yang ditambahkan sari mengkudu masih memenuhi syarat SNI. Kadar air menjadi parameter penting bagi produk pangan sebagai indikasi daya simpan produk tersebut. Menurut Andarwulan (2011), air pada bahan pangan dapat dikaitkan dengan mutu, terutama selama penyimpanan . 
Tabel 2. Perbandingan Kandungan Proksimat dari Berbagai Formula Roti Tawar dengan Penambahan Sari Mengkudu

\begin{tabular}{l|r|r|r|r}
\hline $\begin{array}{c}\text { Paramater proksimat } \\
(\%)\end{array}$ & $\begin{array}{c}\text { Formula 1 } \\
\text { (0 ml sari } \\
\text { mengkudu) }\end{array}$ & $\begin{array}{c}\text { Formula 2 } \\
(50 \text { ml sari } \\
\text { mengkudu })\end{array}$ & $\begin{array}{c}\text { Formula 3 } \\
(100 \mathrm{ml} \\
\text { sari } \\
\text { mengkudu })\end{array}$ & $\begin{array}{c}\text { Formula 4 } \\
(150 \mathrm{ml} \\
\text { sari } \\
\text { mengkudu })\end{array}$ \\
\hline Kadar air & 34,33 & 29,23 & 25,18 & 24,41 \\
Kadar abu & 1,08 & 1,58 & 1,17 & 1,59 \\
Kadar lemak & 5,7 & 5,2 & 6,08 & 7,03 \\
Kadar protein & 8,12 & 8,13 & 8,78 & 9,11 \\
Kadar karbohidrat & 50,77 & 55,86 & 58,79 & 57,86 \\
Gula total & 6,56 & 7,88 & 7,25 & 8,75 \\
\hline
\end{tabular}

Kadar abu pada semua formulasi menunjukkan pada range $1 \%$. Hal ini mengindikasikan bahwa penambahan sari mengkudu tidak mempengaruhi kadar abu roti tawar. Kadar abu yang terdeteksi diduga berasal dari terigu yang digunakan. Menurut David et al (2015), kadar abu pada terigu adalah 1\%. SNI No 01-3840-1995 tentang syarat mutu roti menyatakan bahwa kadar abu yang tidak larut dalam asam maksimal 3\%. Sehingga formulasi roti tawar dengan sari mengkudu masih memenuhi syarat SNI.

Sementara pada kadar lemak, roti tawar dari formula 1 (tanpa sari mengkudu) mempunyai kadar lemak sekitar 5\%. Hal ini dikontribusikan dari telur. Menurut Horbanczuk (2002) dan Dudusola (2010), lemak pada kuning telur sekitar $31,5 \%$. Sedangkan pada roti tawar dengan penambahan sari mengkudu, menunjukkan peningkatan kadar lemak. Hal ini dikarenakan peningkatan terigu yang digunakan. Terigu mempunyai kadar lemak sekitar 1,33\% (David et al , 2015). Meskipun kadar lemak roti tawar yang tanpa maupun dengan penambahan sari mengkudu menunjukkan diatas 5\%, akan tetapi hal ini tidak diatur dalam SNI No 01-3840-1995 tentang syarat mutu roti tawar.

Pada kadar protein, formulasi 1 menunjukkan nilai $8,12 \%$. Hal ini dipengaruhi oleh protein dari terigu yang berkisar 10,23\% (David et al, 2015). Ketika sari mengkudu ditambahkan pada adonan, maka protein yang dihasilkan semakin meningkat seiring dengan peningkatan volume sari mengkudu yang ditambahkan. Hal ini dikarenakan terigu yang digunakan juga semakin meningkat. Terigu mempunyai protein khas bernama gluten, yang berfungsi sebagai penentu sifat elastisitas adonan roti (Nur'Aini, 2011). Kadar protein roti tawar tidak diatur dalam SNI No 01-3840-1995 tentang syarat mutu roti tawar.

Tidak jauh berbeda dengan data protein, kadar karbohidrat roti tawar meningkat seiring dengan peningkatan volume sari mengkudu. Hal ini disebabkan jumlah terigu yang dipakai semakin meningkat. Terigu diketahui mempunyai kadar karbohidrat sekitar 83,60\% (David et al, 2015). Akan tetapi, jika dibandingkan antara formulasi 1 (tanpa sari mengkudu) dan formulasi 2 
(dengan sari mengkudu 50mL), maka terjadi perbedaan jumlah karbohidrat yang terdeteksi, meskipun berat bahan yang digunakan sama. Hal ini disebabkan kadar air diantara keduanya berbeda, sehingga perhitungan karbohidrat dengan metode by difference menunjukkan angka yang berbeda. Kadar karbohidrat roti tawar juga tidak diatur dalam SNI No 01-3840-1995 tentang syarat mutu roti tawar.

Hal yang berbeda ditunjukkan pada total gula, yakni adanya peningkatan total gula pada roti tawar setelah ditambahkan sari mengkudu. Hal ini terlihat pada perbedaan total gula antara formulasi 1 (tanpa sari mengkudu) dan formulasi 2 (penambahan sari mengkudu 50mL). Sari mengkudu terdeteksi mempunyai total gula sebesar 3,46\%. Pada SNI No 01-3840-1995 tentang syarat mutu roti tawar mengatur bahwasanya gula yang terkandung pada roti tawar maksimal $2,5 \%$.

\section{Nilai Energi Roti Tawar dengan Penambahan Sari Mengkudu}

Jumlah takaran saji dan berat per takaran saji untuk semua formula disesuaikan dengan roti tawar komersil yakni 2 lembar per takaran saji dengan berat sejumlah 70g. Terdapat perbedaan jumlah sajian per kemasan antar formula dikarenakan berat adonan yang berbeda pada masing-masing formula (kecuali formula 1 dan 2). Pada berat takaran saji yang sama, energi total yang didapatkan pada formula 1 (kontrol) menunjukkan nilai kalori yang paling yang sepadan dengan nilai kalori roti tawar komersil, yakni 201 kkal, sedangkan nilai kalori formula 2-4 semakin besar sampai mencapai $232 \mathrm{kkal}$.

Tabel 3. Perbandingan Nilai Gizi dari Berbagai Formula Roti Tawar

\begin{tabular}{l|r|r|r|r|r}
\hline \multicolumn{1}{c|}{ Nilai Gizi } & $\begin{array}{c}\text { Formula 1 } \\
\text { (0 ml sari } \\
\text { meng- } \\
\text { kudu) }\end{array}$ & $\begin{array}{c}\text { Formula 2 } \\
\text { (50ml sari } \\
\text { meng- } \\
\text { kudu })\end{array}$ & $\begin{array}{c}\text { Formula 3 } \\
(100 \mathrm{ml} \\
\text { sari meng- } \\
\text { kudu })\end{array}$ & $\begin{array}{c}\text { Formula 4 } \\
(150 \mathrm{ml} \\
\text { sari meng- } \\
\text { kudu })\end{array}$ & $\begin{array}{c}\text { Roti } \\
\text { Tawar } \\
\text { Komersil } \\
*\end{array}$ \\
\hline $\begin{array}{l}\text { Takaran Saji } \\
\text { (lembar) }\end{array}$ & 2 & 2 & 2 & 70 & 2 \\
Berat per & 70 & 70 & 70 & 70 \\
takaran saji (g) & 6 & 6 & 6 & 232 & 5 \\
Jumlah sajian \\
per kemasan
\end{tabular}

Sumber : *Mr.Bread 350g Fresh Bread 
Sedikit perbedaan nilai energi total, lemak, dan karbohidrat pada formula 1 (tanpa penambahan sari mengkudu) dengan roti komersi yang hanya selisih 3 kkal, dikarenakan berat total adonan yang dipakai berbeda. Berat adonan roti komersial tertera sekitar 350g, sedangkan formula 1 sebanyak hampir $390 \mathrm{~g}$ (Tabel 1). Perbandingan antara roti tawar komersil dengan roti tawar dengan penambahan sari mengkudu, selisih kalorinya berkisar 14-34 kkal. Hal ini dikarenakan pada formula 2-4 (dengan penambahan sari mengkudu) terjadi peningkatan lemak, karbohidrat dan total gula. Hal ini selaras dengan kadar lemak, protein, karbohidrat dan total gula pada Tabel 2.

\section{Organoleptik Roti Tawar dengan Penambahan Sari Mengkudu}

Roti tawar yang dibuat berdasarkan formula pada Tabel 1 menghasilkan karakter roti yang berbeda-beda. Hasil uji organoleptik mutu pada roti tawar pada berbagai formula (Tabel 4) menunjukkan bahwa semakin banyak volume sari mengkudu yang ditambahkan, menyebabkan perubahan pada intensitas warna yang dimunculkan. Warna roti tawar berubah menjadi semakin kecoklatan, akibat dari browning yang merupakan reaksi kimia non enzimatis. Reaksi ini berupa reaksi Maillard dan karamelisasi yang sama-sama membutuhkan kontribusi gula (Purlis, 2010). Pada reaksi Maillard, pencoklatan terjadi akibat interaksi antara gugus amino protein dengan gugus gula pereduksi dengan adanya pemanasan (Winarno, 2002). Peristiwa ini juga terjadi pada penelitian Sabovic et al (2014) yang menyatakan bahwa suhu baking mempengaruhi warna roti. Gula penyebab browning diduga berasal dari bahan baku gula pasir yang dipakai dalam pembuatan roti tawar (Tabel 1), dan juga sari mengkudu yang ditambahkan (Tabel 2). Hal ini dibuktikan bahwa dengan bertambahnya volume sari mengkudu, maka penilaian panelis terhadap warna roti tawar semakin coklat.

Selain peningkatan intensitas warna coklat, skor organoleptik aroma juga mengalami kenaikan, yang dikontribusikan dari reaksi Maillard dan karamelisasi. Salah satu aroma yang terbentuk dari reaksi Maillard adalah piroles yang sering ditemukan pada produk berbasis sereal (Boekel, 2006). Selain itu, aroma yang ditimbulkan bisa juga berasal dari bahan baku sumber lemak yang dipakai, seperti susu dan margarin. Sitohang dkk (2015) menyatakan bahwa bau khas adonan bisa ditimbulkan oleh komponen adonan seperti pencampuran telur dan margarin. Menurut SNI No 01-3840-1995 tentang syarat mutu roti tawar, persyaratan bau hanya dinyatakan normal. Sehingga roti tawar semua formula masih kategori bisa diterima. 
Tabel 4.Organoleptik Mutu Roti Tawar dengan Penambahan Mengkudu

\begin{tabular}{|c|c|c|c|c|}
\hline MUTU & $\begin{array}{c}\text { Formula } 1 \\
(0 \mathrm{ml} \text { sari } \\
\text { mengkudu })\end{array}$ & $\begin{array}{l}\text { Formula } 2 \\
(50 \mathrm{ml} \text { sari } \\
\text { mengkudu) }\end{array}$ & $\begin{array}{c}\text { Formula } 3 \\
(100 \mathrm{ml} \text { sari } \\
\text { mengkudu) }\end{array}$ & $\begin{array}{l}\text { Formula } 4 \\
(150 \text { ml sari } \\
\text { mengkudu })\end{array}$ \\
\hline \multirow[t]{2}{*}{ Warna } & 4,63 & 3,85 & 3,90 & 3,40 \\
\hline & Cenderung & Agak & Agak kecoklatan & Coklat muda \\
\hline \multirow[t]{2}{*}{ Aroma } & 2,50 & 2,80 & 3,15 & 3,40 \\
\hline & Agak tidak & Agak sedikit & Agak harum & Cenderung \\
\hline \multirow[t]{2}{*}{ Tekstur } & 4,25 & 3,20 & 2,68 & 2,75 \\
\hline & Empuk & Agak empuk & Kurang empuk & Kurang empuk \\
\hline \multirow[t]{2}{*}{ Rasa } & 3,15 & 2,75 & 2,30 & 2,00 \\
\hline & Agak & $\begin{array}{l}\text { Cenderung } \\
\text { tidak manis }\end{array}$ & Tidak & Tida \\
\hline
\end{tabular}

Hal berbeda terjadi pada nilai organoleptik tekstur, yang justru menurun seiring dengan penambahan sari mengkudu. Hal ini diduga, penggantian peran air oleh sari mengkudu menyebabkan menurunnya kemampuan gluten dalam pembentukan maupun penahanan gas (Roessalina, 2007). Air merupakan bahan yang berperan penting selama pembuatan roti, karena air akan bekerjasama dengan gluten dalam pembentukan konsistensi adonan (Sudarno, 2015). Selain itu, berdasar Tabel 2 menunjukkan bahwa semakin tinggi volume sari mengkudu yang ditambahkan, maka kadar air toti tawar semakin rendah, yang menandakan bahwa roti tawar yang dihasilkan semakin kering.

Pada skor rasa, secara umum semua panelis menyatakan bahwa rasa dari roti tawar keempat formula cenderung tidak manis. Hal ini selaras dengan definisi dari roti tawar yang merupakan produk dari adonan roti yang menggunakan sedikit atau bahkan tanpa gula (Mudjayanto dan Yulianti, 2004). Menurut SNI No 01-3840-1995 tentang syarat mutu roti tawar, persyaratan rasa hanya dinyatakan normal. Sehingga roti tawar semua formula masih dianggap bisa diterima.

\section{KESIMPULAN}

Formulasi roti tawar dengan penambahan mengkudu sampai $150 \mathrm{~mL}$ masih memenuhi syarat mutu roti tawar di SNI No 01-3840-1995 untuk kadar air dan abu, tetapi tidak untuk gula total. Penambahan sari mengkudu menyebabkan peningkatan penggunaan berat terigu, sehingga menyebabkan peningkatan kadar gizinya terutama pada kadar karbohidrat. Akibatnya, nilai energi roti tawar juga meningkat sampai 34 kkal dibanding dengan roti tawar komersil ataupun kontrol. Akan tetapi, penambahan sari mengkudu sampai 
$150 \mathrm{~mL}$ masih bisa diterima secara sensori baik dari segi rasa, warna, aroma maupun tekstur. Sehingga roti tawar dengan penambahan sari mengkudu berpotensi menjadi roti tawar fungsional yang bisa dikomersialisasikan.

\section{DAFTAR PUSTAKA}

Almatsier, S. 2004. Prinsip Dasar Ilmu Gizi. Gramedia Pustaka Utama. Jakarta

Andarwulan, N., Kusnandar, F., Herawati, D. 2011 .Analisis Pangan. Jakarta: Dian Rakyat.

AOAC. 2005. Official Method of Analysis of the Association of Official Analitycal Chemist. 18th ed. Maryland: AOAC International. William Harwitz (ed). United States of America.

Baequny, A., Afiyah, S.H., Elsye, R. 2015. Pengaruh Pola Makan Tinggi Kalori terhadap Peningkatan Kadar Gula Darah pada Penderita Diabetes Mellitus Tipe 2. Jurnal Riset Kesehatan Vol. 4 No. 1

BPOM (Badan Pengawas Obat dan Makanan). 2005. Pedoman Pencantuman Informasi Nilai Gizi Pada Label Pangan. Direktorat Standarisasi Produk Pangan. Deputi Bidang Pengawasan Keamanan Pangan dan Bahan Berbahaya. Badan Pengawas Obat dan Makanan. Republik Indonesia

M.A.J.S. van Boekel. 2006. Formation of flavour compounds in the Maillard reaction. Biotechnology Advances . 24, 230- 233

David, O., Eric, A., Samuel, O.K., Eric, B., Patrick, S. 2015. Proximate Composition and Some Functional Properties of Soft Wheat Flour. International Journal of Innovative Research in Science, Engineering and Technology. Vol. 4, Issue 2, 753-758

Dudusola,I.O. 2010. Comparative evaluation of internal and external qualities of eggs from quail and guinea fowl. Int. Res. J. Plant Sci. 1: 112-115.

Gandama, Petrus. 2012. Pola Konsumsi Roti. BINUS, Jakarta

Horbanczuk, J.O. 2002. The Ostrich. European Ostrich Group, Ribe, Denmark

Laelatunisa, N., Nikmatul, R., Rachmadanti, A., Rista, A. 2019. Efek Penambahan Sari Buah Mengkudu (Morinda citrifolia L.) pada Roti Tawar terhadap Kadar Glukosa Darah Pada Tikus yang Diinduksi Aloksan. Jurnal Food Technology and Halal Science Vol 2 No 2 : 200-208

Legowo, A. M., Nurwantoro, dan Sutaryo. 2005 Analisis Pangan. Badan Penerbit Universitas Diponegoro, Semarang

Lestari, C.A., Tantan, W., dan Hasnelly. 2016. Pengaruh Substitusi Tepung Kacang Koro Pedang (Canavalia ensiformis) Terhadap Karakteristik Roti Tawar. Jurnal Penelitian Tugas Akhir

Mudjayanto, E. S. dan Yulianti, L.N. 2004. Membuat Aneka Roti. Jakarta: Penebar Swadaya

Nur'Aini, A. 2011. Aplikasi Millet (Pennisetum spp) Merah Dan Millet Kuning Sebagai Substitusi Terigu Dalam Pembuatan Roti Tawar: Evaluasi Sifat Sensoris Dan Fisikokimia. Fakultas Pertanian Universitas Sebelas Maret. Surakarta.

Purlis E. 2010. Browning development in bakery products - A review. Journal of Food Engeneering, No. 99, p. 239-249. 
Roessalina W, Y. 2007. Substitusi Tepung Gandum (Triticum aestivum) dengan Tepung Garut (Maranta arundinaceae L) Pada Pembuatan Roti Tawar. Universitas Gadjah Mada. Yogyakarta.

Sabovics, M. Evita, S, and Ruta, G. 2014.The Influence of Baking Temperature on The Quality of Triticale Bread. Foodbalt

Sitohang, K. A. K., Z. Lubis dan L. M. Lubis. 2015. Pengaruh perbandingan jumlah tepung terigu dan tepung sukun dengan jenis penstabil terhadap mutu cookies sukun. Jurnal Rekayasa Pangan dan Pertanian. 3 (3): 308-315.

Standar Nasional Indonesia (SNI).01-3840-1995. Syarat Mutu Roti Tawar. Dewan Standar Nasional. Jakarta.

Stone, H dan Joel, L. 2004. Sensory Evaluation Practices, Edisi Ketiga. Elsevier Academic Press, California, USA

Sudarmadji, S., B. Haryono, Suhardi, 1997. Prosedur Analisa untuk Bahan Makanan dan Pertanian. Liberty, Yogyakarta.

Sudarno. 2015. Eksperimen Pembuatan Roti Tawar Substitusi Tepung Kulit Ari Kedelai Varietas US. No.1. Skripsi. Jurusan Pendidikan Kesejahteraan Keluarga. Fakultas Teknik. Universitas Negeri Semarang

Sugiharto, R., Dyah, K., dan Tias, A. 2016. Efek Penambahan Antioksidan Terhadap Sifat Sensori dan Lama Simpan Roti Tawar yang Difortifikasi Dengan Minyak Ikan. Jurnal Teknologi Industri \& Hasil Pertanian Vol. 21 No.2

Winarno, F.G. 2002. Kimia Pangan dan Gizi. Gramedia Pustaka Utama.Jakarta 